\title{
Metabolising risk: food scares and the un/re-making of Belgian beef
}

\section{Pierre Stassart}

SEED (Socio-Economie Environnement Développement), Fondation Universitaire

Luxembourgeoise, Avenue de Longwy 185, 6700 Arlon, Belgium; e-mail: stassart@ful.ac.be

\section{Sarah J Whatmore}

Geography Discipline, The Open University, Walton Hall, Milton Keynes MK7 6AA, England; e-mail: s.whatmore@open.ac.uk

Received 15 January 2002; in revised form 23 July 2002

\begin{abstract}
In this paper we explore the event of foodscares as an example of what Callon calls 'hot situations', in which the landscape of competing knowledge claims is at its most molten, and alternative production and consumption practices galvanise new modes of sense-making against the market and state-sanctioned rationalities of industrialisation. Through a case study of the Belgian cooperative Coprosain and its meat products, we examine the 'stuff' of food as a ready messenger of connectedness and affectivity in which 'risk' is transacted as a property both of the growing distance between the spaces of production and consumption and of the enduring metabolic intimacies between human and nonhuman bodies.
\end{abstract}

"the small habits of consumption, typically daily food habits, can perform a percussive role in organizing large-scale consumption patterns ... made up of much more complex orders of repetition and improvisation."

Appadurai (1996, page 68)

\section{Introduction}

Listeria; Salmonella; E. coli; dioxin; chemical, hormone, and antibiotic residues; and, scariest of all perhaps, 'mad cows', are now familiar interlopers in the cheap abundance and superfluous choices enjoyed by those of us accustomed to an industrial diet. The 'yuk factor', as Burke so felicitously labels such gut apprehensions (1998), shifts ambivalently through this catalogue of unwelcome familiars. What begins as a catalogue of errors by accident - 'rogue' bacteria and proteins - whose presence signals a failure in the clinical production and distribution of foodstuffs, becomes a catalogue of errors by design - the traces of scientific and economic rationalisations of plant and animal bodies which, in their multifarious incarnations as human foods, become incorporated into our own (Fitzsimmons and Goodman, 1998). Unlike Beck's neat demarcation between 'natural hazards' and 'social risks', the benchmark that heralds his Risk Society (1989), the social and the natural are not so readily distilled in this parade of disturbing hybridities. The metabolic impressions that the flesh of others imparts to our own are an enduring axiom of social relations with the nonhuman world and the porosity of the imagined borders which mark 'us' off from 'it'. The potency of this vector of intercorporeality seems to grow as the moments and spaces of cultivating and eating, animal and meat, plant and fruit, become ever more convoluted. The troubling spectres of fleshy mutability that haunt the shadowy regions between field and plate mass with particular intensity in the event of food scares. Such events have become endemic in the relentless industrialisation of food over the last half century and are now emblematic of the threadbare fabric of trust (dis)connecting industrial food production and consumption as we enter the 21st century (Griffiths and Wallace, 1998). 
As citizens, consumers, and academics in two European countries, whose political landscapes have been deeply marked by a succession of food scares over more than two decades, we are struck by the creative disruption which such events engender. Their effects are felt not only in the institutionalised routines of market and policy networks, and the habits and practices of everyday life, but also in the tacit assumptions and conceptual 'black holes' of agrifood research. In this vein, food scares are classic exemplars of what Callon calls "hot situations" or "hybrid forums" in which "everything becomes controversial [in] the absence of a stabilised knowledge base" and "is overflowing continuously, with an ever-growing, ever-more-varied cast of characters" (1998, page 260). Yet, with the exceptions of work by Fischler (1990), Nygard and Storstad (1998), and Murdoch et al (2000), who allude to the relationship between food scares and renewed concerns with food quality, attention to the social, political, and ethical significance of these events is remarkable by its absence. We want to suggest that there are at least two reasons why prevailing research agendas and accounts have failed to register these landmarks in popular and public sense-making. The first is a tendency for research to fracture along an economic-cultural faultine and, through conversations and alignments with political economy and cultural studies, respectively, to reiterate a compartmentalisation of production and consumption (see Goodman, 1999). Staple analytical concepts such as commodity chains (Friedland et al, 1981) and 'filières agro-alimentaires' (agrifood supply chain) (Allaire and Boyer, 1995) share a tendency to configure the geographies of food as a unidirectional transposition from field to plate, in which consumption is cast as the "end of the road for goods and services" (Appadurai, 1996, page 66). Even as they take the spaces of shopping, cooking, and eating more seriously, too many investigators of food consumption seem content to accept this terminal location-isolating these practices from their effective entanglements with those of other moments in the assemblage of agrifood networks (for example Bell and Valentine, 1997; Lupton, 1996). The second reason for the lack of analytical purchase on food scares that we would identify is the neglect of 'foodstuffs' themselves in the terms of political economy and cultural studies. The stuff of food constantly shifts register between matter and meaning; animal and meat; calories and flavours - stretching and folding the time-spaces of here and now, 'us' and 'them', producing and consuming, in complex and contested ways (Probyn, 1999). But this fleshy traffic in/through things tends to be restricted analytically to their pliant animation by something else-human intention-excluding the affectivity of 'things' on their own account and that can resist and deflect human designs (see Graves-Brown, 2000; Latour, 2000).

In this paper we explore the stuff of food as a ready messenger of connectedness and affectivity that transacts 'risk' as a property both of the growing distances between the spaces of production and consumption and of the enduring metabolic intimacies between human and nonhuman bodies (see Whatmore, 2002). We argue that this metabolic modality of consumer apprehension congeals in the event of food scares against the assurances of experts, intensifying alignments of what Wynne calls 'profane knowledges' (1996) in/through the assemblage of 'alternative' food networks such as those transacting 'organics' and/or 'animal welfare'. Both in Belgium and in Britain, these links are already beginning to be traced empirically by research instigated by nongovernmental organisations (NGOs) (see Mormont and van Huylenbroeck, 2001; Soil Association, 2000; Stassart, 1999). The contribution we seek to make is to flesh out this metabolic mode of ordering in theoretical terms, bringing actant network theory (ANT) and risk analysis into conversation through a case study of one such alternative food network in the making. The case is that of Coprosain, a Belgian meat cooperative that distances its livestock practices from the industrial ones which have been exposed 
by a series of food scares, and reconfigures relations between farmers, consumers, and animals in the process. In particular, we want to consider the importance of entanglements of consumer and producer knowledge practices to the assemblage and sustainability of new institutional forms in transacting the interval between production and consumption. These entanglements, we suggest, render the connections between the treatment of living animals and the quality of their meat transparent, such that their flesh becomes an effective 'spokesproduct' for the collective mediation of risk and distance, substantiating trust in the network.

\section{Coprosain: alternative food networkings}

Coprosain is an agricultural cooperative that processes and markets the produce of around fifty farms. It began by dealing in all manner of produce, ranging from farmhouse cheeses to home-cured meats, but has gradually become specialised in meat production and distribution through its own network of farm shops and markets. The cooperative's assemblage over twenty-five years, and the ways in which consumers have made their presence felt in its collective performance, is multifaceted and amenable to analysis from a number of different perspectives, depending upon one's point of entry into the network (see O'Neill and Whatmore, 2000). Here, we explore this imbroglio of farmers, consumers, and products by taking three different journeys or 'cuts' through their alternative food networkings. The first cut follows the shifting corporealities of Coprosian's flagship produce and its strengthening alignment against a succession of food scares related to industrial meat in Belgium in the 1980s. The second cut tracks one of the most successful envoys of the network, the 'Bœuf Fermier' trademark that transacts distance and risk between farm and table for that most troubling of flesh-beef. The third cut focuses on the silent partners in these transactions, the butchers and the beef itself that, between them, convene a space for the renegotiation of meat quality through which consumers can register their apprehensions in the network and so help to generate new envoys of trust.

\section{Cut 1-journeying in a land of food scares}

The biography of the Coprosain cooperative, like any collective history, is littered with dead ends and missed paths which are as important to its assemblage as any neat sequence of events that can be read into it with hindsight. How can we pick a way through this multiplicity of farm produce; heterogeneity of production practices; and diversity of consumer knowledges towards an understanding of Coprosain's organisational fabric? Here, we follow its flagship produce or, to borrow Callon's phrase, its 'spokesproducts' (produits porte-paroles) (1989, pages 15-18). These are distinguishable by their capacity to 'speak on behalf of' the many humans and nonhumans that populate the collective. If we suggest that some products are more vocal than others, it is to evoke the multisensual register of message bearers admitted by the material semiotics of Serres (1995) and others and which consumers apprehend as substantiating differences in the flesh from industrially produced meat. It is also because the fleshy envoys of taste, texture, colour, and smell in animal body products are more potent messengers of intercorporeality than are other human foodstuffs (Fiddes, 1991). In other words, a farm chicken, a bunch of onions, and a pound of flour do not 'speak' to consumers in the same way. In the case of Coprosain, we would discern three phases in its configuration of production-distribution relations, each of which corresponds to a different collective spokesproduct (table 1, over).

Of course, a spokesproduct is always a contestable and fallible configuration, so this periodisation into three phases necessarily oversimplifies the complex potentialities of Coprosain's networkings. Between 1975 and 1985 the cooperative sold its 
Table 1. The three phases of production-distribution relations in Coprosain.

\begin{tabular}{|c|c|c|c|c|}
\hline Phase & Spokesproduct & Marketing network & $\begin{array}{l}\text { Space-time } \\
\text { configuration }\end{array}$ & $\begin{array}{l}\text { Producer } \\
\text { characteristics }\end{array}$ \\
\hline $1975-85$ & $\begin{array}{l}\text { farm chicken } \\
\text { 'Poulet Fermier' }\end{array}$ & $\begin{array}{l}\text { local markets and } \\
\text { consumers' groups }\end{array}$ & face-to-face & rural entrepreneurs \\
\hline $1985-95$ & $\begin{array}{l}\text { farm beef } \\
\text { 'Bœuf Fermier' }\end{array}$ & butchers' shops & $\begin{array}{l}\text { mediated } \\
\text { proximity }\end{array}$ & $\begin{array}{l}\text { mixed family } \\
\text { businesses }\end{array}$ \\
\hline $1995-$ & $\begin{array}{l}\text { farm pork } \\
\text { 'Porc Fermier' }\end{array}$ & wholesale markets & at a distance & outdoor pig farmers \\
\hline
\end{tabular}

produce through local markets and consumer groups. One creature stands out as the spokesproduct of these experimental exchanges - the 'farm chicken' (Poulet Fermier'). ${ }^{(1)}$ The potency of this chicken resided in its embodiment of difference from the carcass of the industrial chicken. Although the urgency of food-safety issues waxed and waned with the intensity of media attention (for example, Le Soire 1965), the association between 'battery chickens' and hormone use made a more lasting mark on the public imagination. For example, in "La Montagne", a very popular song, the French singer, Jean Ferrat, used it to contrast the wholesome quality of country living with that of the city, whose residents have only a tower block and a hormone-chicken supper to go home to.

“... Leur vie, ils seront flics ou fonctionnaires

De quoi attendre sans s'en faire

Que l'heure de la retraite sonne

Il faut savoir ce que l'on aime

Et rentrer dans son H.L.M.

Manger du poulet aux hormones"

Jean Ferrat "La Montagne" (1965). (2)

As one of the most closely scrutinised and engineered of domesticated creatures (see Boyd and Watts, 1997), the chicken has become a primary envoy in the Belgian context of the intercorporeal vulnerabilities and metabolic intimacies performed through eating flesh. The industrial practices of battery-chicken production, and the associated feeding and pharmaceutical-treatment regimes, all contributed to a growing public wariness of the perverse rationalities of industrial agriculture. ${ }^{(3)}$

In 1985, Coprosain bought its first butcher's shop. With this purchase, the 'farm chicken' began to be overshadowed by a nobler spokesproduct of the butcher's skillsred meat and its standard bearer 'farm beef' ('Bœuf Fermier'). At first, Coprosain's

(1) The market vernacular 'poulet fermier' signals an identity between the chicken and the farmer in French which does not quite translate into English, where the vernacular equivalent is more usually locational than personal, that is, between the chicken and the farm.

(2) A rough translation of these lines from Jean Ferrat's popular song "La Montagne" (The Mountain) (1965) might be

"What a life ... those cops and bureaucrats

with nothing to look forward to as they wait

to clock off.

Accustomed to liking what they're given,

it's home to their tower blocks

and hormone-chicken dinners again."

(3) For a contemporary expression of this public resistance to the perverse rationality of industrial chicken production, see the emergence and development of the production network 'Label Rouge' and its spokesproduct the 'farm chicken' (Sylvander, 1995). 
acquisition of butchers' shops was not directly motivated by food-safety concerns, notwithstanding its vigorous opposition to the murky practices of the cattle-rearing business. Despite being forbidden by law, the use of hormones in livestock farming was already routine and was a cause of concern within the sector ( La Boucherie Belge 1988). However, consumers accustomed to buying 'farm chicken' began to draw parallels with beef just as cattle began to assume the burden of growing public anxieties about the food-safety implications of hormone use associated with industrial meat production in Belgium (as in other countries). Demand for 'farm beef' rose through the 1980s as Coprosain formalised its nonindustrial credentials by introducing a 'production contract' in 1987 that excluded the use of antibiotics, hormones, and artificial growth promoters, and which was extended to the exclusion of animal products and bonemeal from cattle feed in 1989. The cooperative went so far as to explore ways of further strengthening this producer-consumer compact by means of certification procedures that were unprecedented at the time in their reliance on the outside inspection of farm practices. But these early efforts were overwhelmed by the eruption of the hormone issue into public scandal with the publication of an investigation by the Belgian Consumers Association that exposed long-suspected practices under the headline "Fake beef and real hormones" (Test Achats 1989). This exposé was closely followed by an article in which the likelihood of hormone residues in industrial beefsteak was calculated as "one in five" (Test Achats 1990). In this context the government had little option but to intervene to assuage public anxieties and to bolster the beef market by introducing an official certification scheme. The scheme, introduced in 1992, recognised Coprosain, among other cooperatives, as a role model for alternative meat-production and marketing practices and adopted the Coprosain 'production contract' and its template, lending new credence to the 'farm beef' trademark as a collective spokesproduct.

Coprosain further distanced its practices from those of industrial meat producers in the late 1990s by taking the radical decision to reduce the cooperative's reliance on commercially produced animal feed and to produce more of its feed requirements on its own farms. This decision accompanied another shift in the collective's primary spokesproduct - from beef and the label 'Bœuf Fermier' to pork and the label 'Porc Fermier' (figure 1). In part, this shift reflects the intensification of food scares in Europe during this decade, particularly the erosion of beef sales in the wake of the BSE/vCJD [(bovine spongiform encephalopathy/variant Creutfeldt-Jakob disease crisis in the United Kingdom (Ratzan, 1998)], and the dioxin scandal in industrial animal feeds in Belgium (Van der Houtte and Pâque, 2000). Moreover, in these troubled times the difference between 'industrial' and 'alternative' meat production was more obvious in the contrast between the rearing factories and foul-smelling slurry of industrial pig production and the return of pigs to the 'outdoors', than in the treatment of cattle. In this climate, Coprosain's realignment in anticipation of the risks associated with industrial animal feedstuffs put them ahead of the market trend.

The shifts in collective spokesproduct traced here were intricately bound up with gathering consumer anxieties about the risks inherent in industrial meat production which were kept constantly in the public eye by a succession of food scares. They also articulate the learned skills and adaptive practices of farmers in the Coprosain cooperative in the realisation of their commitment to producing mead differently. In the

\begin{tabular}{c}
$\begin{array}{c}\text { 'Poulet Fermier' } \\
\text { (farm chicken) }\end{array} \rightarrow \longrightarrow$\begin{tabular}{c|} 
'Bœuf Fermier' \\
(farm beef)
\end{tabular}$\longrightarrow \rightarrow$\begin{tabular}{c|} 
'Porc Fermier' \\
(farm pork)
\end{tabular} \\
\hline
\end{tabular}

Figure 1. The progression of Coprosain spokesproducts. 
next cut, through Coprosain networkings, we focus on the second of these phases in its collective performance, by tracing its envoy - the label 'Bœuf Fermier'.

\section{Cut 2-'Bouf Fermier': transacting distance/risk from farm to table}

The switch from chicken to beef as the spokesproduct of the Coprosain collective coincided with a lengthening of the network in which the face-to-face staging of transactions between producers and consumers in farmers' markets was replaced with more complex arrangements involving a number of intermediaries - most importantly, those associated with butchery. The sustaining of metabolic connectivities between producers and consumers through these more convoluted networkings relied on a collective messenger to trace and secure passage in ways that are 'legible' to differently positioned constituencies (Karpik, 1996, page 539). To understand how the distant intimacies of this alternative food network are freighted, we turn to an envoy that the collective enlists to 'speak' in its name - the Coprosain trademark (figure 2). ${ }^{(4)}$ We will consider in turn its composition, its message, and the connectivities it affords.

The envoy is not just a logo, or a label. On the contrary, it is a collective signature that marks all Coprosain produce as kin and is writ large on the fascia of butchers' shops. To characterise this collective mode of identification we can distinguish three material semiotic elements that are closely entwined in the affectivity of the envoy. The first is the marketing slogan "from the farm to your table", to which we have already referred. Here, the curt juxtaposition of spaces of the slogan is allied to a visual shortcircuiting of the food-supply chain in which the production spaces of the farmyard and the warm conviviality of the kitchen table where consumption is sited are aligned through the body products that move between the two. Second, the name Coprosain itself forges a fleshy bond through which farmers, consumers, and produce are allied in the collective shorthand of a $C O$-operative marketing of $P R O$-duce that is healthy $(S A I N)$. Here the 'sain' encapsulated in the collective identity of the network echoes the dual virtues of bodily and spiritual health of the Roman 'mens sana in corpore sanum' (a healthy mind in a healthy body) but also, as we shall explore in the 'third cut' below, incorporates more than human well-being in its collective embrace. If initially the farmers of Coprosain had presented their cooperative endeavours under the shortcircuit slogan to emphasise "a new type of relationship between producers

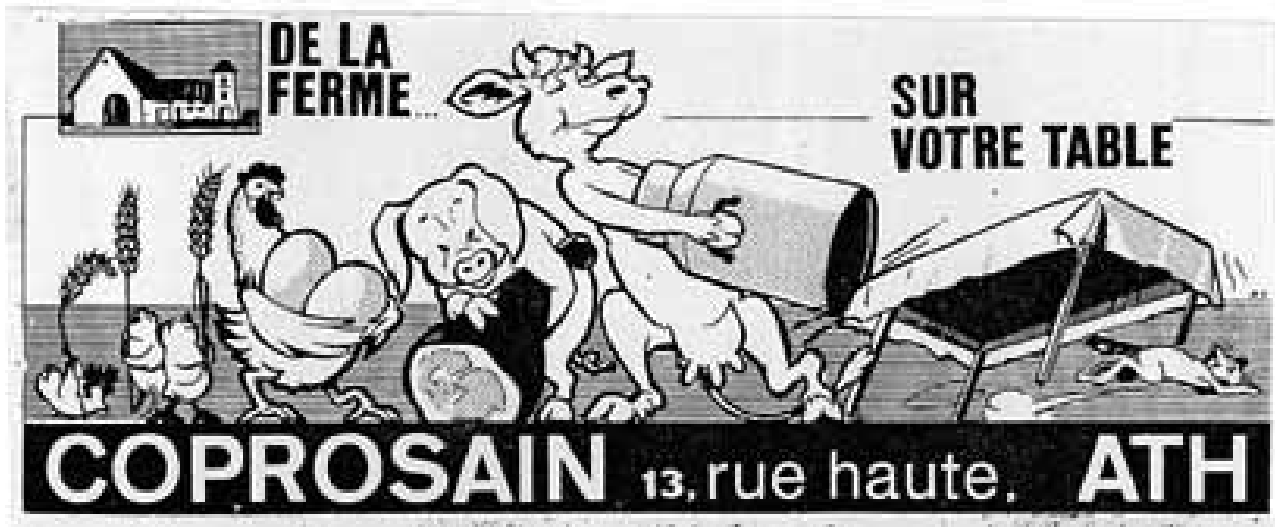

Figure 2. The Coprosain trademark.

(4) The specifications of 'Bœuf Fermier' would usefully amplify what the envoy is saying, but lack of space prevents us from detailing them here (see Stassart, 1999). 
and consumers" (Coprosain, 1979), gradually this polyvalent envoy has been realigned by consumers to amplify their overriding concerns with health. Thus, as one woman consumer explains,

"they [the farmers of Coprosain] are looking to understand their marketing network beyond their region. They want to know if the direct relationship between consumers and producers can really motivate consumer groups, if it could do the business. But I feel that the 'short circuit' notion that they have been using misses the mark with many people ... its healthy products, natural products, and those without additives that really motivate people like me. Right now the word that makes people react most is 'additive' ... . Like Vie Feminine [a women's magazine] which is keeping a record of all the children's sweets that use additives ..." (consumer interview, 10 August 1998; translated).

To this extent, consumers have effected an inversion in the modality of the collective such that from now on Coprosain will mean healthy produce (direct from the farm).

The third element in this material semiotic imbroglio is the animal iconography of the trademark that associates animal well-being with human health and invests the farmer with responsibility for the proper care of his or her animals and for their treatment after they leave the farm. Here, the trademark depicts the collective enthusiasm of the animals to get themselves to the table, each body product bearing witness to the care and consideration received at each stage in its transformation from animal to meat. This storyline applies to all the products that freight the qualities of the farmer in the activities of the animals, like the cow that carries the pail of fresh milk; the pig that bears the ham, and the pair of chicks that peck the grain in the farmyard. In contrasting this community of embodied individuals with the indifference of industrial body products, Coprosain articulates a collective reclamation of living animals, and farming as husbandry. The cast of animals as body subjects as well as body products in this alternative food networking invites a 'kinship in the flesh' between animal and human health. As envoys of the Coprosain collective, these creatures articulate animal well-being as the public face of good farming and good eating. Here, Coprosain's metabolic mode of ordering most clearly demonstrates its suspension between producers and consumers - a double metabolism as Goodman (1999) would put it, in which the corporeal register of human and animal life connects the spaces of farm and table. But this mode of ordering exercises its own deletions (Law, 1994, page 112), excising some players to enhance the coherence of others even as their absent presence transacts the intervals between producers and consumers, animals and meat. To get from the farm to your table, these charming animals have to encounter the butcher and the bloody thrust of the knife! Why disguise beef cattle as milk cows? What is the significance of this silent violence?

\section{Cut 3-where's the butcher, where's the beef?}

Although cut 2 enables us to affirm that cattle really live on farms, as matters stand, how they end up in consumers' stomachs remains obscure. The problem lies in getting the animal on the hoof to the joint on the table, that is, in translating the lively heterogeneity of cattle in the field into the fleshy homogeneity of meat on the plate. The Belgian confederation of butchers has perfected a method of cutting animals up that effects just such a translation, slicing more and more of the same through the practice of 'anatomical' butchery in which a standardisation of carcass is both assumed and honed. Butchering disassembles an animal through repetitious 'cuts' in/of the flesh (for example, filet, rump, and sirloin steaks) whose cooking and eating properties are known to consumers. In Belgium, the discipline of turning animals into meat is configured through the space of the carving table (Stassart, 2002). The carving table 
convenes an alignment between modes of consumption and production such that changes in rearing practices cannot be effected without changes in eating practices. To modify what happens on the carving table is to disturb what goes on in the field and the kitchen. Coprosain is not exempt from having to negotiate this 'Belgian' way of cutting meat. In describing the approach of Belgian butchers as 'anatomical' (figure 3), professional commentators mean to emphasise their surgical skill in tracing the grain (le fil) of the flesh with the knife to isolate lean muscle from fatty tissues, sinews, and bones (Van der Aa, 1992).

Since its formal adoption by the profession in 1974, anatomical butchering has encouraged a corporeal standardisation that has seen a particular breed-the Belgian Blue (Blanc Bleu Belge) - become the physiognomic model of beef cattle (figure 4). The hypermuscled build characteristic of this new breed of cattle epitomises the industrial cow as a meat machine whose production is systematically rationalised from the

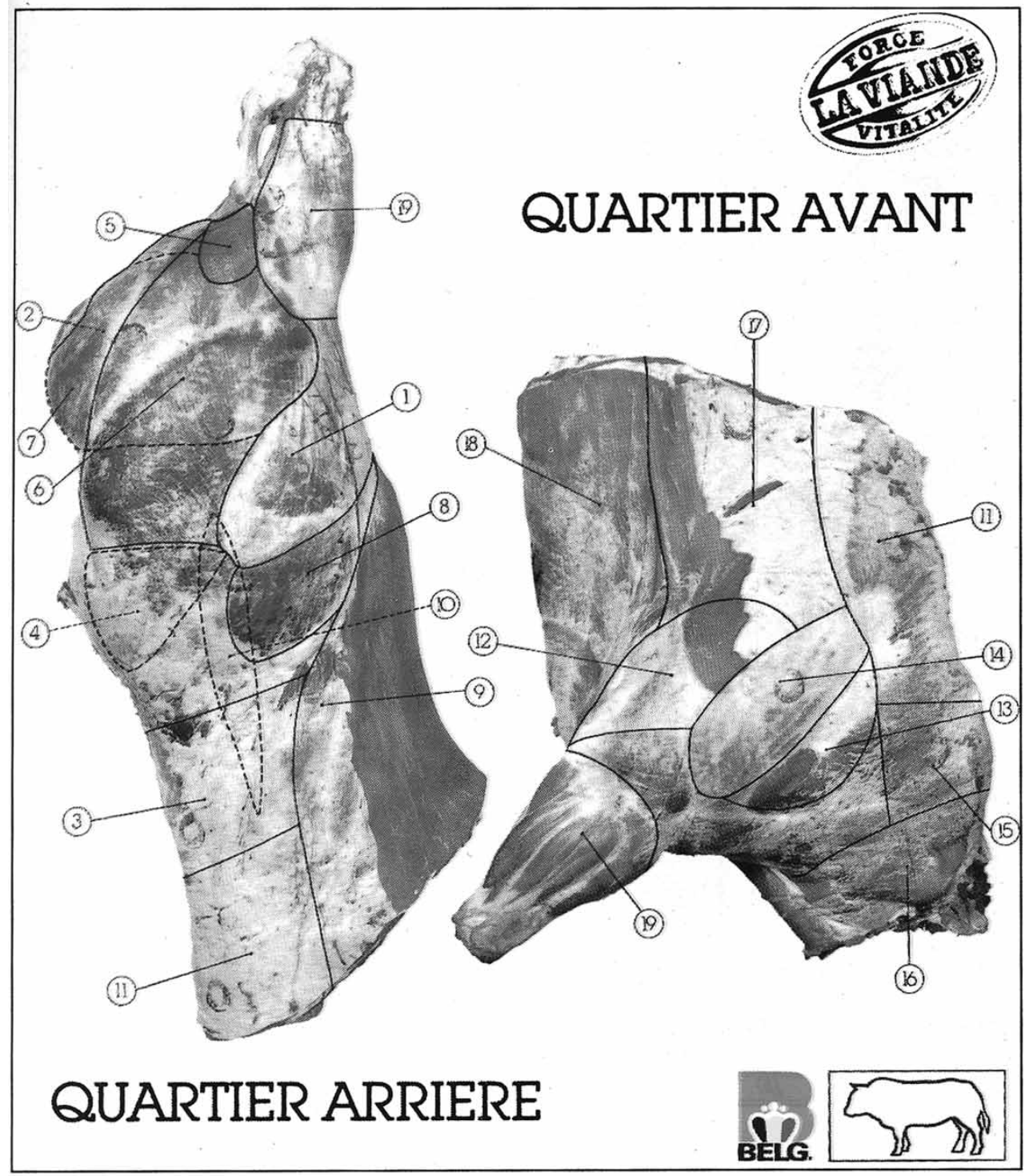

Figure 3. Anatomical butchering. 
genetic engineering of its muscular development to the routine use of artificial insemination, embryo transfer, and Caesarean delivery. This massive creature conforms anatomically to the sociotechnical disciplines of butchery and embodies an unrivalled dead-weight yield. However, the Belgian Blue's extraordinary size and shape arouses suspicion amongst some consumers who have been quick to equate the breed with the use of hormones.

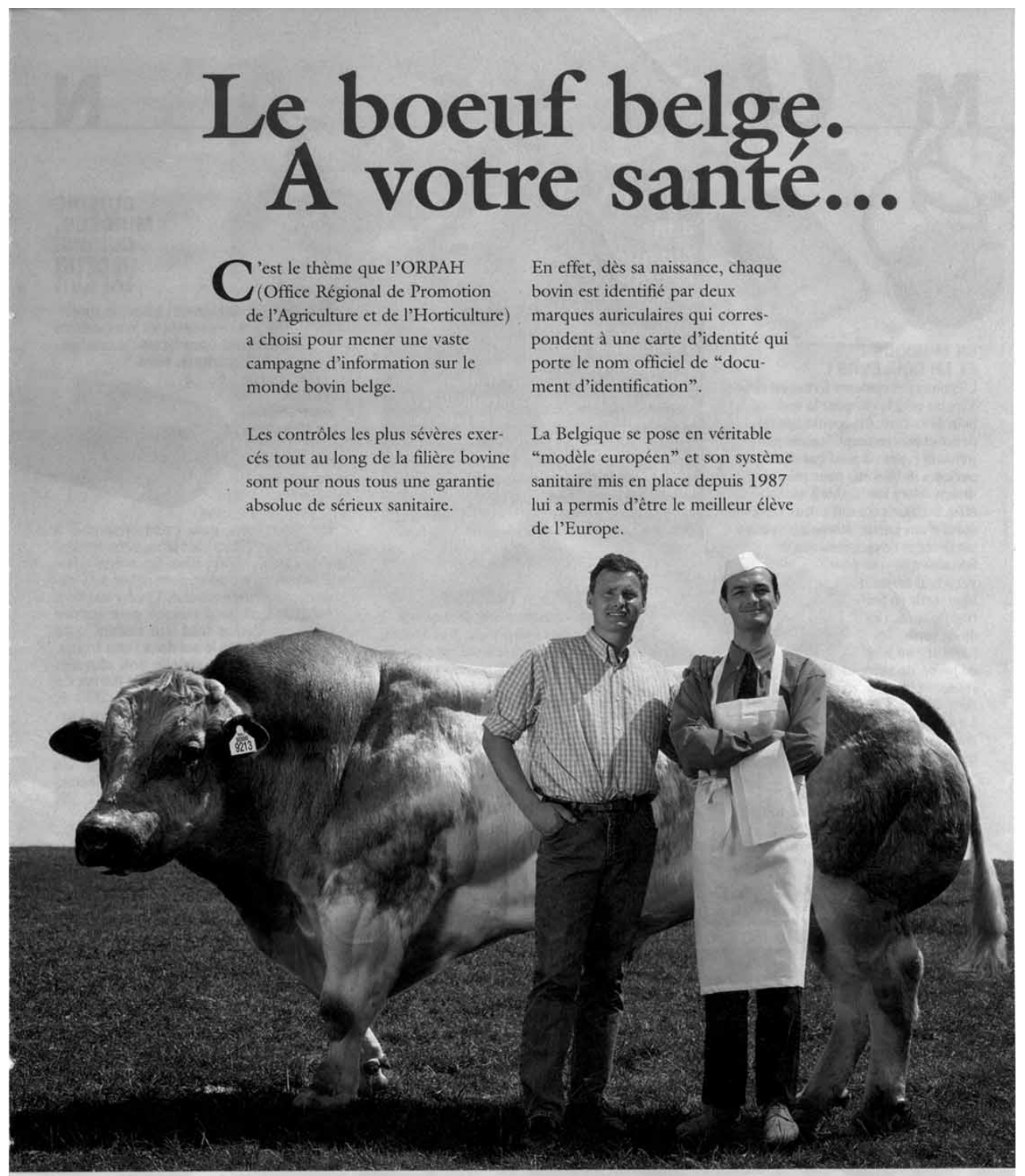

... Les contrôles sanitaires les plus sévères. Demandez la brochure d'info/consommateurs à votre boucher lors de votre prochaine visite.

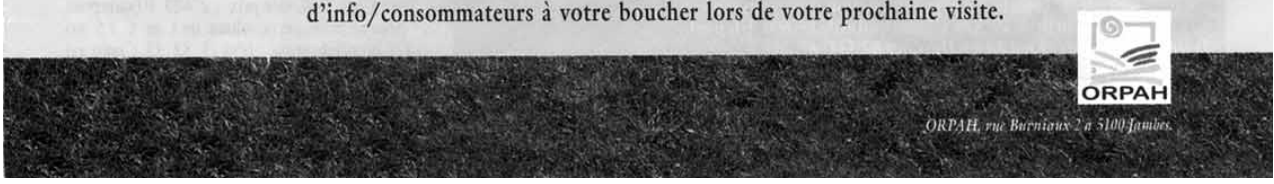

Figure 4. The Belgian Blue bodybuilder (source: advertising campaign of the Regional Office of Promotion of Agriculture and Horticulture, 1996). 
“Are there really no hormones? Above all, the Belgian Blue has made people really aware of the problem. What must the farmers have given them to get animals like that? I remember asking my cousin what they gave them ... he claimed it was nothing at all but I don't believe it ...” (consumer interview 10 August 1998).

In Belgium, these suspicions gained the Belgian Blue the nickname 'Ben Johnson' beef, after the notorious Canadian sprinter who was stripped of his gold medal at the Seoul Olympic games for having used banned anabolic steroids (Vandemeulebroucke, 1993, pages $44-51$ ). The suspicion that this hypermuscled breed was associated with the use of hormones was well founded. Despite the unanimous condemnation of consumers' groups, professional circles acknowledged the widespread use of such body-building practices in the industry's drive to maximise profit margins (La Boucherie Belge 1988, page $9-13)$.

The effects of anatomical butchering are not limited to the 'look' of the breed. On the contrary, they are written into the very flesh of the cow. Cutting 'with the grain' of the flesh to purify muscle from fat systematically, dissociates the flavour of the meat from the fatty tissues and emphasises the single quality of leanness as the tasteless standard of industrialised meat. How to align the Belgian Blue to a metabolic mode of ordering when its 'outsized' haunches embody the risks of industrial food production for many consumers, and its rearing binds farmers more closely to the disciplines of anatomical butchering? Little wonder that the butchers and the beef are deleted from the collective envoy of Coprosain - the label 'Bœuf Fermier'. Can it be accommodated in the collective performance of an alternative food network woven between the commitments of producers and consumers to doing things differently?

Coprosain set about such an accommodation by adopting a new certification scheme, using the label 'farm-reared Belgian Blue' (Blanc Bleu Fermier), which sought to invest the Belgian Blue with a new respectability by guaranteeing the exclusion of hormones through an independent inspection regime. More than another marketing

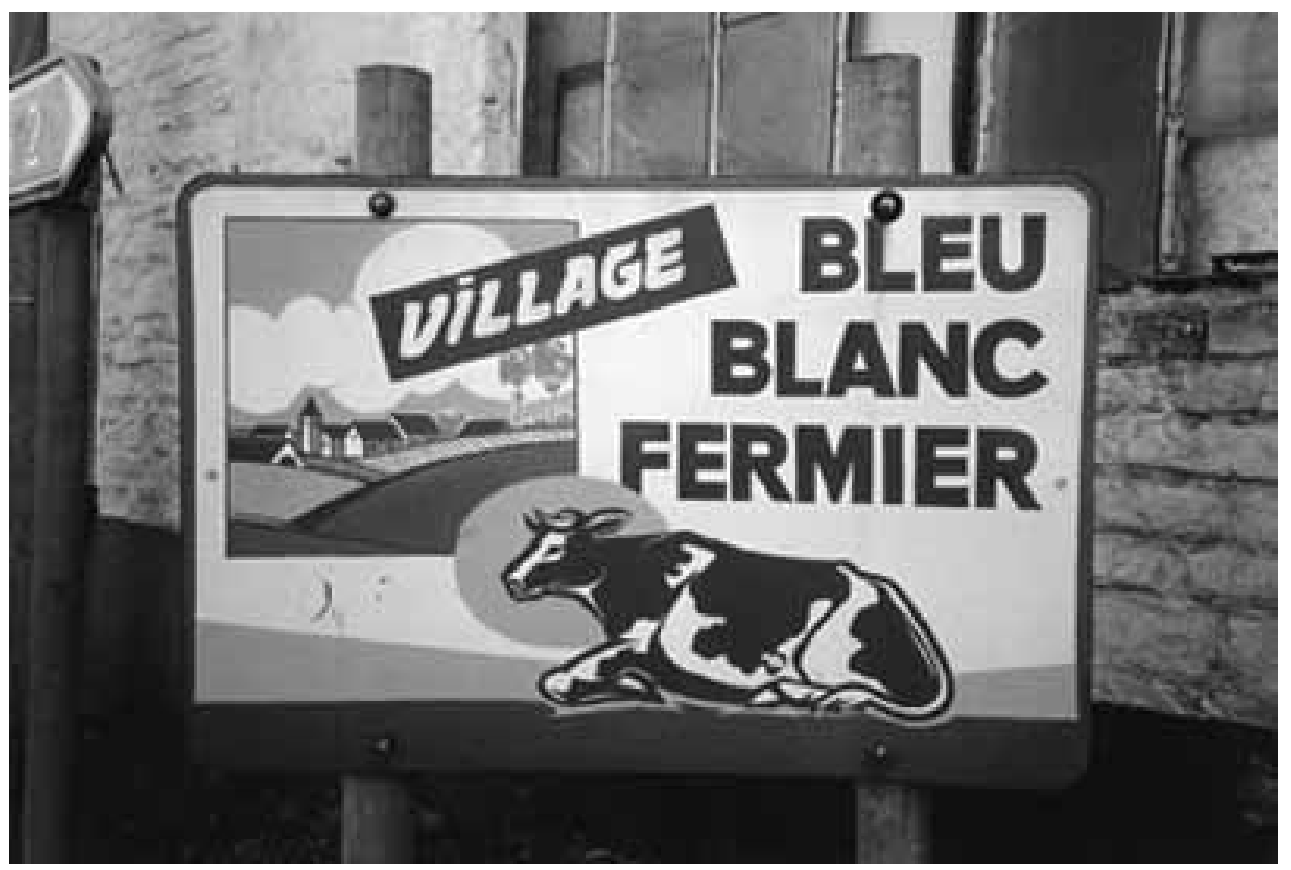

Figure 5. 'Farm reared Belgian Blue'? 
campaign, this new envoy of Coprosain was afforded substance through the patient consolidation of a series of specifications about the treatment of cattle on the farm that translated into legible consumer benchmarks (Thévenot, 1995). Like the 'farm chicken' of old, these specifications included a minimum of $75 \%$ animals being born on the farm; low threshold stocking densities; farmer accountability for birth-toslaughter treatment records; and restrictions on feed ingredients. In the case of feed specifications, for example, Coprosain regulations stipulate that

"... if the farmer does not produce his own feed, he may purchase feed from a regional miller who complies with Items I and II in the foregoing specifications.

Inspections will be carried out at regular intervals" (Coprosain, 1997).

In addition, consumers are invited to visit the cooperative's farms to witness these collective commitments to raising beef cattle differently from the industrial model, even in the case of its standard-bearer the Belgian Blue, in action. It is not sufficient to slap on a label like 'farm-reared Belgian Blue' (Black Bleu Fermier) on the meat to get away from the attributes of the breed (figure 5).

But where the brand image merely reduces the animal to an absent presence-grass without cattle, Coprosain's marketing campaign is fortified by its laborious attention to the specification of practices that more effectively incorporate the Belgian Blue into its metabolic mode of ordering.

\section{Metabolising risk}

Consumer knowledge practices challenge the distribution of (ir)rationalities and risks in the contemporary industrialisation of food, and make alternative kinds of sense to that performed through the calculi of profitability or regulatory audit. Such 'profane' knowledges are practised through the kinds of "small acts of consumption" that tend to be analytically overlooked but which, as Appadurai (1986) suggests, can be a "percussive role" in the organisation of "large scale consumption patterns". Such repercussions gain particular momentum in the event of food scares when, under intense media scrutiny, the (ir)rationalities of industrial production become substantiated as, for example, in the bodybuilder physiognomy of the Belgian Blue. Against all the assurances of scientific and public authorities, it is the 'hormone chicken' and kindred message-bearers in the flesh that have freighted risk in the vernacular of food choices and anxieties for over thirty-five years. But their subversive potency is being honed to more positive effect with the rise of alternative food networks (Bové and Dufour, 2001). Here, new alignments of producer and consumer knowledge practices are taking shape through a shared corporeal of human and animal well-being, or what we have characterised as a metabolic mode or ordering.

We would emphasise three key aspects of this metabolic mode of ordering, glimpsed through our case study of Coprosain. First, the significance of spokesproducts in fleshing out the 'middle ground' between production and consumption and, thereby, substantiating trust in the network. As our analysis of their shifting embodiment suggests, these spokesproducts extend the register of significance beyond the symbolic and cognitive to a fuller array of bodies/languages in the idiom of material semiotics. It is this fleshing out that accounts, in our view, for Coprosain's ability to accommodate the 'bodybuilder' Belgian Blue in its 'alternative' network more effectively than the ill-fated efforts of the conventional meat industry to rehabilitate its image (for example, the 'Walloon' quality label), without addressing the substance of consumer concerns. Second, the performative alignment of diverse agencies, practices, and sites in the network is provisional and open-ended, rather than structural and predetermined. Theoretically, this underlines the well-known affinities between ANT and the rhizomatics of Deleuze and Guattari (1988). More importantly, this polyvalence signals a key feature of the 
durability of alternative food networks: their capacity for switching direction. In the case of Coprosain, one is struck by a looseness of collective fit that both permits and anticipates perturbations, accommodating food scares by a shift in spokesproduct or by reconciling the shortcircuiting emphasis of farmers and the health emphasis of consumers in the collective trademark.

And third, the collective configuration of 'quality' and 'trust' as sociomaterial properties forged between producers and consumers relies on an imbroglio of heterogeneous intermediaries, including trademarks, product specifications, and better tasting/smelling/looking meat, to strengthen network connectivities (Lamine, 2001). Privileging neither production nor consumption, this metabolic mode of ordering populates the middle ground, translating between the knowledge practices of animal husbandry and their body subjects on the farm and those of food consumption and their body products on the plate. But this open-ended exchange of energies between humans and nonhumans engenders its own lacunae, as in the case of Coprosain, for example, in the effaced disciplines of anatomical butchering and the bodybuilder Belgian Blue.

The case of Coprosain suggests that in 'hot' situations like food scares, when the landscape of competing knowledge claims is at its most molten, consumers rely heavily on experiential knowledges that reinforce ontological continuities between human bodies and those we eat. Such knowledges are profane insofar as they contradict the labours of social theory as well those of food authorities and their scientific advisors to entrench a division between nature and society (see Fitzsimmons and Goodman, 1998). If consumption is to amount to more than 'identity shopping', as cultural studies would have it, or 'the end of the road' for agricultural commodities as political economy seems to suggest, then our theoretical and methodological repertoire for understanding the knowledge practices made flesh in the everyday conduct of provisioning, cooking, and eating need to be radically overhauled (see Probyn, 1999). If in effect healthy food is predicated on healthy animals, then the monstrous efficiencies embodied in the Belgian Blue make no sense (Van de Graaf and Grin, 1999). But the non-sense of this meat machine exceeds the disgust it engenders in consumers. For farmers it is the standardisation of production practices imposed by the breed and its allies in the bioscience, veterinarian, and butchery trades that makes it suspect, threatening to erode the autonomy and integrity of their skill and livelihoods. It is the associational confluence of these differing configurations of risk in/through the Coprosain network that redistributes and strengthens resistance to the rationalities of industrial foods between producers and consumers, not least by generating a collective vernacular for doing things differently and therein renegotiating the risks and qualities of meat.

\section{References}

Allacre G, Boyer R, 1995 The Great Transformation of Agriculture (INRA Economica, Paris)

Appadurai A, 1986 The Social Life of Things: Commodities in Cultural Perspective (Cambridge University Press, Cambridge)

Appadurai A, 1996 Modernity at Large: Cultural Dimensions of Globalization (Minnesota University Press, Minneapolis, MN)

Beck U, 1989 Risk Society (Sage, London)

Bell D, Valentine G, 1997 Consuming Geographies: We Are Where We Eat (Routledge, London)

Bové J, Dufour F, 2001 The World is Not for Sale: Farmers Against Junk Food (Verso, London)

Boyd W, Watts M, 1997, "Agro-industrial just-in-time: the chicken industry in postwar American capitalism", in Globalising Food Eds D Goodman, M Watts (Routledge, London) pp 192-225

Burke D, 1998, “The 'yuk' factor”, in Consuming Passions Eds S Griffiths, J Wallace (Mandolin, Manchester) pp $48-57$

Callon M, 1989 La Science et ses Réseaux [Science and its networks] (La Découverte, Paris)

Callon M, 1998, "An essay on framing and overflowing: economic externalities revisited by sociology", in The Laws of Markets Ed. M Callon (Blackwell, Oxford) pp 244-269 
Coprosain, 1979, "Rules of conduct", Internal mimeo, Coprosain, SCRL Chemin des peupliers 24 B-7400, Ath, Belgium

Coprosain, 1997, "Product specification for beef", Internal mimeo, Coprosain, SCRL Chemin des peupliers 24 B-7400, Ath, Belgium

Deleuze G, Guattari F, 1988 A Thousand Plateaus: Capitalism and Schizophrenia (translated by B Massumi) (Athlone Press, London)

Fiddes N, 1991 Meat: A Natural Symbol (Routledge, London)

Fischler C, 1990 L'Homnivore [Man the eater] (Odile Jacob, Paris)

Fitzsimmons M, Goodman D, 1998, "Incorporating nature: environmental narratives and the reproduction of food", in Remaking Reality. Nature at the Millennium Eds N Castree, B Willems-Braun (Routledge, London) pp 194-220

Friedland W, Barton A, Thomas R, 1981 Manufacturing Green Gold (Cambridge University Press, Cambridge)

Goodman D, 1999, "Agro-food studies in the age of ecology: nature, corporeality, biopolitics" Sociologia Ruralis $3917-38$

Graves-Brown P (Ed.), 2000 Matter, Materiality and Modern Culture (Routledge, London)

Griffiths S, Wallace J (Eds), 1998 Consuming Passions (Mandolin, Manchester)

Karpik L, 1996, "Dispositif de confiance et engagements crédibles" [Device establishing trust and credible commitments] Sociologie du travail $4527-550$

La Boucherie Belge 1988, "Un thème, un débat, la qualité de la viande" [One theme, one debate, the quality of meat] La Boucherie Belge 5 9-13

Lamine C, 2001, "Food risks and the construction of trust: choosing organic food or not, the examples of bread, wine and meat", paper presented to the 19th European Congress for Rural Sociology, 3 - 7 September, Dijon, France; copy available from École des Hautes Études en Sciences Sociales (EHESS), Marseilles, France

Latour B, 2000, "When things strike back - a possible contribution of science studies to the social sciences" British Journal of Sociology 51 107-123

Law J, 1994 Organising Modernity (Blackwell, Oxford)

Le Soir 1965, "Le danger des procédés chimiques d'engraissement" [The danger of chemical fattening processes], 3 September, page 3

Lupton D, 1996 Food, the Body and the Self (Sage, London)

Mormont M, Van Huylenbroeck G, 2001 A la recherche de la qualité [Research on the question of 'quality'] (Édition de l'ULG, Liège)

Murdoch J, Marsden T, Banks J, 2000, "Quality, nature and embeddedness" Economic Geography 76(2) $107-125$

Nygard B, Storstad O, 1998, "De-globalisation of food markets? Consumer perception of safe food: the case of Norway" Sociologia Ruralis 38(1) 35-53

O'Neill P, Whatmore S, 2000, "The business of place: networks of partnership, property and produce" Geoforum 31(2) $281-307$

Probyn E, 1999, "Beyond food/sex: eating and the ethics of existence" Theory, Culture and Society 16(2) $215-228$

Ratzan S (Ed.), 1998 The Mad Cow Crisis: Health and Public Good (UCL Press, London)

Serres M, 1995 Angels: A Modern Myth (translated by F Cowper) (Flammarion, Paris)

Stassart P (Ed.), 1999 Du savoir aux saveurs: 101 chemins pour une alimentation de qualité [From knowing to savouring: 101 ways to quality food] FUL/Vredeseilanden-Coopibo, Arlon-Leuven

Stassart P, 2002 Produits fermiers, entre qualification et identité [Farm products between quality and identity] (Peter Lang, Brussels)

Sylvander B, 1995, "Convention de qualité: concurrence et coopération. Cas du Label Rouge dans la filière volailles" [Quality conventions: concurrence and cooperation. The case of red label chicken], in La grande transformation de l'agriculture Eds G Allaire, R Boyer (INRAEconomica, Paris) pp $73-96$

Test Achats 1989, "Dossier 'Faux boeufs et vraies hormones" [Briefing on 'False beef and real hormones'] Test Achats Magazine number 318, pages 26-43

Test Achats 1990, "Toujours la viande aux hormones" [Always meat with hormones] Test Achats Magazine number 307, pages 36-40

Thévenot L, 1995, "Conventions, des marchés aux normes" [Conventions: from markets to standards] La grande transformation de l'agriculture Eds G Allaire, R Boyer (INRA-Economica, Paris) pp $33-52$ 
Van de Graaf H, Grin J, 1999, "Policy instrument, pratique réfléchie et apprentissage: implication pour la gouvernabilité à long terme et la démocratie" [Policy instruments, reflexive practise and learning: implications for long term governability and democracy] Gestion négociée des territoires et politiques publiques (L'Harmattan, Paris) pp 63-89

Vandemeulebroucke J, 1993, "Hoe maak je Ben Johnson-vee" [How do you make Ben Johnson beef?] De hormonenmaffia (Hadewijch, Antwerpen) pp 44-51

Van der Aa W, 1992 Manuel du boucher charcutier [Hand book of a butcher] (MIM, Duerne)

Van der Houtte P, Pâque L, 2000, 'Enquête Parlementaire sur l'organisation de la production de viande, de produits laitiers et d'œufs en Belgique et sur les responsabilités politiques dans le cadre de la crise de la dioxine" [Parliamentary enquiry into the organisation of meat, diary, and egg production in Belgium and of political responsibilities in the context of the dioxin crisis], Document 50 0018/008, Chambre des représentants, Brussels; http://www1.dekamer.be/FLWB/pdf/50/0018/50K0018008.pdf

Whatmore S, 2002 Hybrid Geographies (Sage, London)

Wynne B, 1996, "May the sheep safely graze? A reflexive view of the expert - lay knowledge divide", in Risk, Environment and Modernity: Towards a New Ecology Eds S Lash, B Bzerszynski, B Wynne (Sage, London) pp $44-83$ 